\title{
KOMPOSISI IKAN HASIL TANGKAPAN MENGGUNAKAN CANTRANG DI SELAT MADURA
}

\author{
Cantrang (Dragged Gear) Catch Composition in Madura Strait \\ Oleh: \\ Fis Purwangka ${ }^{1 *}$, Hamba Ainul Mubarok ${ }^{1}$, Furqan ${ }^{2}$ \\ ${ }^{1}$ Departemen PSP FPIK IPB \\ ${ }^{2}$ Mahasiswa Program Magister TPL IPB \\ ${ }^{*}$ Korespondensi: fis@psp-ipb.org
}

\begin{abstract}
ABSTRAK
Perairan Selat Madura termasuk ke dalam wilayah 11 kabupaten/kota di Jawa Timur, yaitu Kota Surabaya, Kabupaten Bangkalan, Kabupaten Sampang, Kabupaten Pamekasan, Kabupaten Sumenep, Kabupaten Sidoarjo, Kabupaten Pasuruan, Kota Pasuruan, Kabupaten Probolinggo, Kota Probolinggo, dan Kabupaten Situbondo. Pada tahun 2013, di 11 kabupaten/kota tersebut beroperasi kurang lebih 102.350 unit penangkapan ikan dan menghasilkan lebih dari 50 jenis ikan dan udang (Laporan tahunan statistik perikanan tangkap di Jawa Timur tahun 2014). Produksi perikanan tangkap yang didaratkan di 11 kabupaten/kota sebanyak 193.358 ton (BPS Jatim). Kajian ini bertujuan untuk mengetahui komposisi hasil tangkapan ikan dengan menggunakan alat tangkap cantrang serta menilai indeks kekayaan jenis ikan di perairan Selat Madura. Penelitian dilakukan dengan menggunakan Kapal KM Angin Sorga dengan alat tangkap cantrang. Pengumpulan koleksi ikan dilakukan dengan alat tangkap cantrang menggunakan metode swept area. Penarikan jaring dilakukan di dua stasiun. Kelimpahan individu sebaran dan indeks kekayaan spesies dihitung dengan menggunakan rumus dari Margalef (1958) yaitu: $\mathrm{D}=(\mathrm{S}-1) / \log (\mathrm{N})$. Hasil tangkapan ikan yang terkumpul dari ke 2 stasiun seluruhnya adalah berjumlah 549 individu terdiri dari 38 spesies yang mewakili 29 famili, dengan rincian sebagai berikut: stasiun $\mathrm{S} 1$ = 532 individu, terdiri dari 36 spesies yang mewakili 28 famili; stasiun S2 = 17 individu, terdiri dari 9 spesies yang mewakili 8 famili. Perhitungan nilai Indeks Kekayaan Spesies (nilai D) pada dua stasiun pengamatan memperlihatkan, stasiun S1 nilai kekayaan spesies sebesar $(D)=12,84$, stasiun S2 nilai $D=6,50$. Berdasarkan kriteria indeks kekayaan jenis menurut Jorgensen et al (2005), kondisi kedua stasiun termasuk dalam kategori baik.
\end{abstract}

Kata kunci: Selat Madura, swept area, indeks kekayaan spesies.

\begin{abstract}
Madura Strait waters encompassed 11 districts/cities in East Java, namely the City of Surabaya, Bangkalan Regency, Sampang Regency, Pamekasan Regency, Sumenep Regency, Sidoarjo Regency, Pasuruan Regency, Pasuruan City, Probolinggo Regency, Probolinggo City and Situbondo Regency. In 2013, there were no 102,350 fishing units in 11 districts / cities and produced more than 50 fishes and shrimp species (2014 annual report on capture fisheries statistics in East Java). Fisheries production landed in 11 regencies / cities is 193,358 tons (BPS Jatim). This study objectives are finding out catches using cantrang fishing gear and also fish species richness index in the Madura Strait habitat. The study was conducted using the Angin Sorga Ship with cantrang fishing gear. Collecting fish collection is done by cantrang fishing using swept area method. Cantrang fishing operations are carried out at two stations. Individual abundance distribution and species richness index are calculated using the formula from Margalef (1958), which is: $D=(S-1) / \log (N)$. The results collected from the 2 stations were 549 individuals consisting of 38 species representing 29 families, with detail as follows: $S 1$ stations $=532$
\end{abstract}


individuals, consisting of 36 species representing 28 families; station $S 2=17$ individuals, consisting of 9 species representing 8 families. Fish species richness index (D) on two observation stations, station $S 1$ species richness index $(D)=12.84$, station $S 2 D=6.50$. Based on fish species richness index criteria according to Jorgensen et al (2005), the conditions of both stations are in the good category.

Keywords: Madura strait, swept area, species richness index.

\section{PENDAHULUAN}

Selat Madura merupakan daerah penangkapan ikan yang cukup potensial. Karakteristik oseanografi, Selat Madura memiliki ombak yang relatif tenang, dan aliran air perairan Selat Madura memiliki pola aliran air dari timur ke barat dan sebaliknya. Posisi Selat Madura yang diapit pulau Jawa dan Madura yang strategis dan kondisi lingkungan yang mendukung maka secara langsung Selat Madura memberikan peranan penting dalam perekonomian Jawa Timur dari sisi sumberdaya, selain itu, Selat Madura memberikan konstribusi dalam sektor transportasi, baik itu penyeberangan dari dan ke Pulau Madura maupun daerah-daerah lain di Indonesia. Selat Madura selama ini juga dimanfaatkan sebagai jalur lalulintas transportasi ekspor-impor Indonesia dari wilayah Jawa Timur. Beberapa wilayah perairan Selat Madura terdapat kandungan minyak dan gas (migas), sehingga terdapat beberapa lokasi industri migas. Besarnya pemanfaatan Selat Madura membuat tekanan terhadap perairan Selat Madura juga semakin besar, yang akhirnya akan memicu degradasi kondisi lingkungan.

Perairan Selat Madura termasuk ke dalam wilayah 11 kabupaten/kota di Jawa Timur, yaitu Kota Surabaya, Kabupaten Bangkalan, Kabupaten Sampang, Kabupaten Pamekasan, Kabupaten Sumenep, Kabupaten Sidoarjo, Kabupaten Pasuruan, Kota Pasuruan, Kabupaten Probolinggo, Kota Probolinggo, dan Kabupaten Situbondo. Pada tahun 2013, di 11 kabupaten/kota tersebut beroperasi kurang lebih 102.350 unit penangkapan ikan dan menghasilkan lebih dari 50 jenis ikan dan udang (Laporan tahunan statistik perikanan tangkap di Jawa Timur tahun 2014). Produksi perikanan tangkap yang didaratkan di 11 kabupaten/kota disajikan pada Tabel 1.

Tabel 1 Produksi perikanan tangkap di 11 kabupaten/kota

\begin{tabular}{|c|c|c|c|c|c|c|c|c|}
\hline \multirow{2}{*}{ No } & \multirow{2}{*}{ Kab/Kota } & \multicolumn{7}{|c|}{ Produksi Perikanan Tangkap (ton) } \\
\hline & & 2010 & 2011 & 2012 & 2013 & 2014 & 2015 & 2016 \\
\hline 1 & Kota Surabaya & 9.493 & 7.120 & & & 7.803 & & 10.578 \\
\hline 2 & Kab. Bangkalan & 21.037 & 22.156 & 23.486 & 24.660 & 24.967 & 22.916 & 25.694 \\
\hline 3 & Kab. Sampang & 12.350 & 8.048 & 10.642 & 9.297 & 9.840 & 7.268 & 8.943 \\
\hline 4 & Kab. Pamekasan & 19.578 & 20.435 & 20.603 & 20.264 & 22.522 & 4.503 & 23.190 \\
\hline 5 & Kab. Sumenep & 43.386 & 44.491 & 44.639 & 45.736 & 47.092 & 8.503 & 46.673 \\
\hline 6 & Kab. Sidoarjo & 12.840 & 13.145 & 12.895 & 14.660 & 10.918 & 14.410 & 14.908 \\
\hline 7 & Kab. Pasuruan & 7.037 & 7.608 & 7.814 & 7.634 & 7.943 & 8.405 & 9.024 \\
\hline 8 & Kota Pasuruan & 1.786 & 2.110 & 1.835 & 1.809 & 1.473 & 3.843 & 6.072 \\
\hline 9 & Kab. Probolinggo & 9.474 & 9.550 & 9.588 & 9.665 & 13.068 & 17.679 & 17.945 \\
\hline 10 & Kota Probolinggo & 36.088 & 18.352 & 10.201 & 13.042 & 18.647 & 15.166 & 19.741 \\
\hline \multirow[t]{2}{*}{11} & Kab. Situbondo & 5.594 & 6.012 & 6.092 & 7.871 & 8.355 & 7.104 & 13.590 \\
\hline & TOTAL & 178.663 & 159.027 & 147.795 & 154.638 & 172.628 & 109.797 & 196.358 \\
\hline
\end{tabular}

Sumber : BPS Provinsi Jawa Timur

Data tersebut menunjukkan fluktuasi produksi perikanan tangkap dari tahun 2010 - 2016. Data merupakan produksi dari 11 kabupaten/kota yang memiliki wilayah perairan di Selat Madura. 
Kajian ini bertujuan untuk mengetahui komposisi hasil tangkapan ikan dengan menggunakan alat tangkap cantrang serta menilai indeks kekayaan jenis ikan di perairan Selat Madura.

\section{METODE PENELITIAN}

Penelitian ini dilaksanakan di perairan Selat Madura, di selatan Kabupaten Sumenep. Lebih jelas disajikan pada Gambar 1.

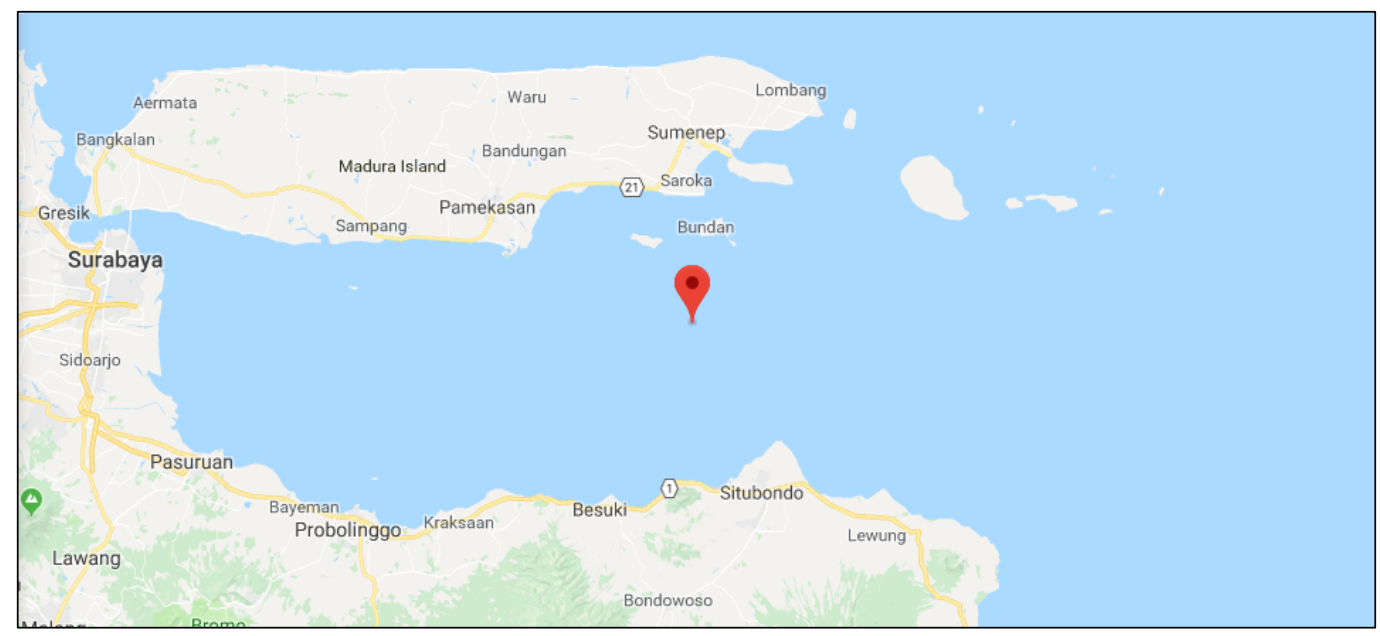

Gambar 1 Peta lokasi kajian

Penelitian dilakukan dengan menggunakan Kapal KM Angin Sorga dengan alat tangkap cantrang. Pengumpulan koleksi ikan dilakukan dengan alat tangkap cantrang menggunakan metode swept area. Penarikan jaring dilakukan di dua stasiun, posisi stasiun dan peta lokasi dapat dilihat pada Tabel 2.

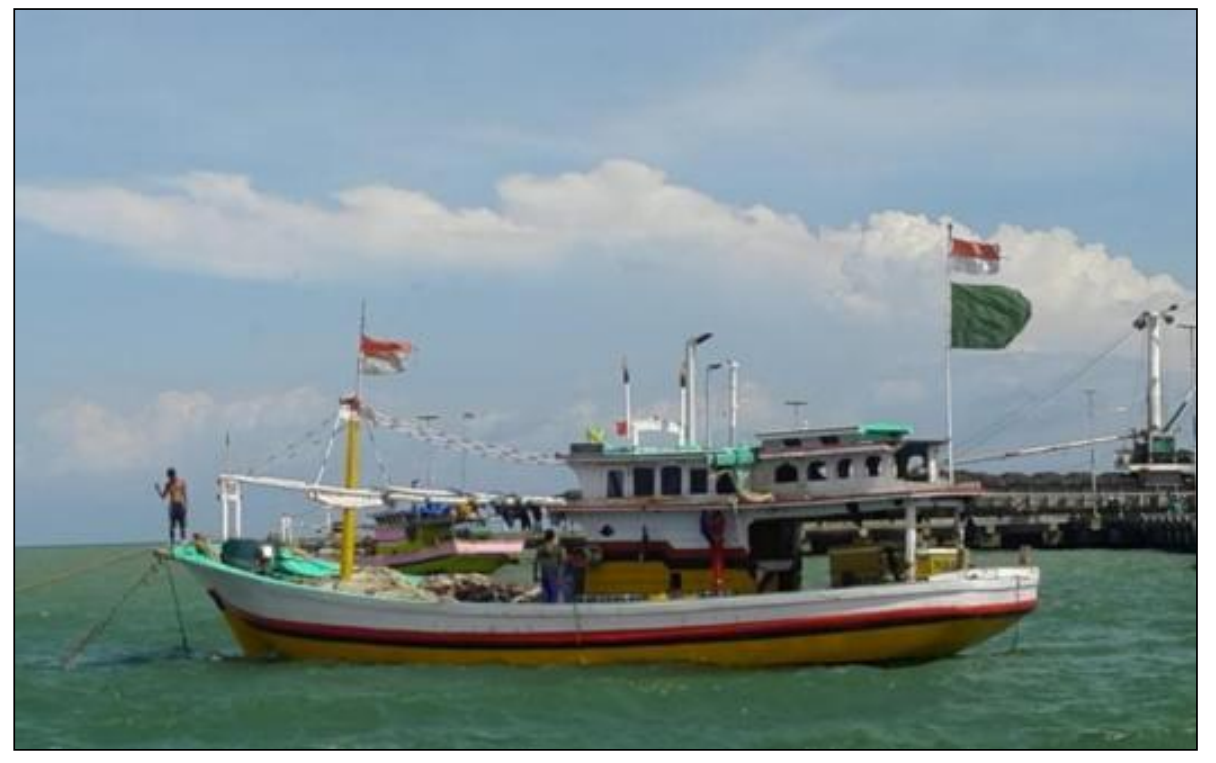

Gambar 2 KM Angin Sorga

Saat operasi, waktu jaring diturunkan (setting) dan waktu jaring dinaikkan (hauling), terlebih dahulu diidentifikasikan posisi menggunakan peralatan "GPSMap 585”. Waktu yang dibutuhkan untuk penarikan jaring pada setiap stasiun adalah 1 jam dengan kecepatan kapal 2,7 - 3 knot dan panjang tali 6-8 kali kedalaman laut. 
Tabel 2 Posisi cantrang pada waktu pemasangan (setting), waktu pengangkatan (hauling), serta kedalaman perairan

\begin{tabular}{|c|c|c|c|c|c|}
\hline \multirow{2}{*}{$\begin{array}{l}\text { Stasiun/ } \\
\text { Tanggal }\end{array}$} & \multicolumn{2}{|c|}{ Setting } & \multicolumn{2}{|c|}{ Hauling } & \multirow{2}{*}{$\begin{array}{c}\text { Depth } \\
\text { (m) }\end{array}$} \\
\hline & Posisi & Waktu & Posisi & Waktu & \\
\hline $\begin{array}{c}\text { S1 } \\
(14 / 05 / 16)\end{array}$ & $\begin{array}{c}\text { S } 7^{0} 23^{\prime} 12.1 " \\
\text { E } 113^{0} 52^{\prime} 12.0 "\end{array}$ & $5: 46: 22$ & $\begin{array}{c}\text { S } 7^{0} 23^{\prime} 01.5^{\prime \prime} \\
\text { E } 113^{0} 51^{\prime} 17.0 "\end{array}$ & $6: 45: 33$ & $50-60$ \\
\hline $\begin{array}{c}\text { S2 } \\
(14 / 05 / 16)\end{array}$ & $\begin{array}{l}\text { S } 7^{0} 22^{\prime} 53.1^{\prime \prime} \\
\text { E } 113^{0} 54^{\prime} 16.0^{\prime \prime}\end{array}$ & $7: 24: 47$ & $\begin{array}{c}\text { S } 7^{0} 22^{\prime} 48.8^{\prime \prime} \\
\text { E } 113^{0} 53^{\prime} 18.5^{\prime \prime}\end{array}$ & $8: 20: 24$ & $50-60$ \\
\hline
\end{tabular}

Selanjutnya, hasil tangkapan ikan tersebut dipisahkan menurut spesiesnya, diukur panjang, berat dan dihitung jumlahnya. Contoh ikan yang belum diketahui spesiesnya dilakukan pengawetan menggunakan larutan formalin 10 \% untuk selanjutnya dibawa ke laboratoriun Tingkah Laku Ikan, Dept PSP, FPIK-IPB untuk dianalisa. Kelimpahan individu sebaran dan indeks kekayaan spesies dihitung dengan menggunakan rumus dari Margalef (1958) yaitu:

$\mathrm{D}=(\mathrm{S}-1) / \log (\mathrm{N})$ 1

Dimana $\quad \mathrm{D}=$ lndeks kekayaan spesies

$\mathrm{S} \quad=$ Jumlah spesies yang terdapat dalam koleksi

$\mathrm{N}$ = Jumlah individu yang terdapat dalam koleksi

Kriteria kekayaan jenis dapat dilihat pada tabel berikut.

Tabel 3 Kriteria indeks kekayaan jenis menurut Jorgensen et al (2005)

\begin{tabular}{lc}
\hline \multicolumn{1}{c}{ Kriteria } & Indeks kekayaan jenis \\
\hline Baik & $>4,0$ \\
Moderat & $2,5-4,0$ \\
Buruk & $<2,5$ \\
\hline
\end{tabular}

\section{HASIL DAN PEMBAHASAN}

\section{Deskripsi Alat Tangkap Cantrang}

Alat tangkap cantrang terbuat dari bahan jaring, seperti kantong besar berbentuk seperti kerucut dan semakin ke belakang ukurannya semakin mengerucut. Cantrang tidak dilengkapi alat pembuka mulut jaring berupa gawang (beam) atau papan (otter board) dan untuk penarikan tali selambar menggunakan winch kapstan dari atas kapal (BPPI, 1999 dalam Aji et al, 2013).

Cantrang dioperasikan pada dasar perairan yang bersubstrat pasir dan tidak terdapat karang dengan ikan demersal sebagai target penangkapan. Alat tangkap cantrang terdiri dari bagian utama, yaitu sayap, badan serta kantong. Sayap mempunyai fungsi sebagai penggiring ikan masuk kedalam badan, dan untuk selanjutnya ikan akan masuk ke dalam kantong. Kantong merupakan tempat untuk menampung ikan hasil tangkapan (Aji et al, 2013). 


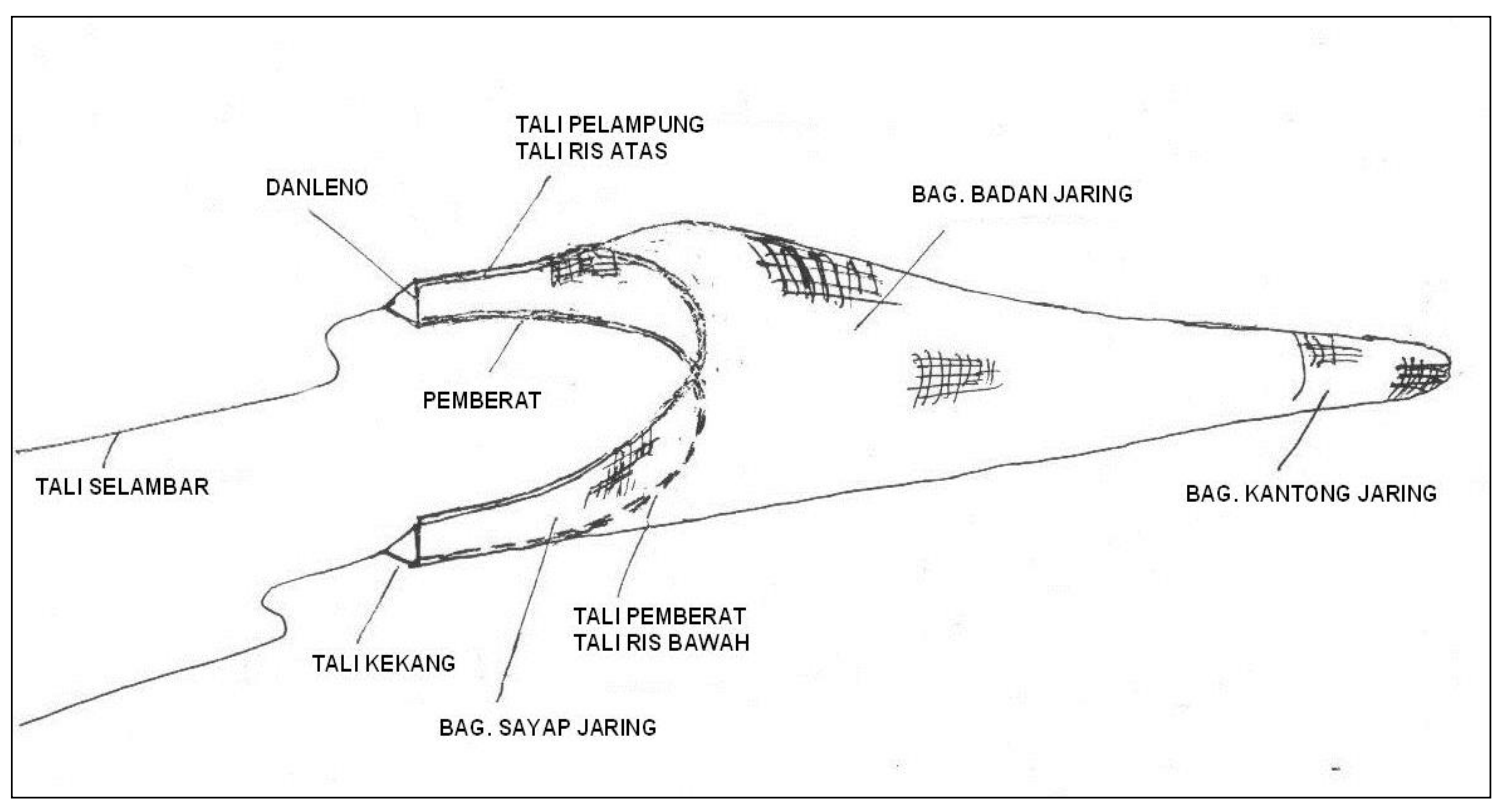

Gambar 3 Ilustrasi pukat tarik cantrang (Bambang, 2006)

\section{Spesies dan Kelimpahan Ikan}

Hasil tangkapan ikan yang terkumpul dari ke 2 stasiun seluruhnya adalah berjumlah 549 individu terdiri dari 38 spesies yang mewakili 29 famili (Tabel 4.) dengan rincian sebagai berikut: stasiun S1 = 532 individu, terdiri dari 36 spesies yang mewakili 28 famili; stasiun S2 = 17 individu, terdiri dari 9 spesies yang mewakili 8 famili.

Hasil tangkapan ikan pada Stasiun 1 sebanyak 532 individu, terdiri dari 36 spesies yang mewakili 28 famili. Spesies-spesies yang mendominasi adalah : Nemipterus tambuloides dari famili Nemipteridae dengan jumlah tangkapan 264 individu sebagai peringkat pertama, menyusul urutan kedua adalah Priacanthus tayenus dari famili Priacanthidae dengan jumlah tangkapan 94 individu, urutan ketiga adalah Mugil cephalus dari famili Mugilidae dengan jumlah tangkapan 26 individu, Carangoides talamparoides dari famili Carangidae dengan jumlah tangkapan 25 individu sebagai urutan keempat; Leiognathus sp. dari famili Leiognathidae dan Sphyraena sp. dari famili Sphyraenidae dengan jumlah tangkapan 19 individu sebagai urutan kelima, urutan keenam Fistularia petimba dari famili Fistularidae dengan jumlah tangkapan 12 individu, sedangkan spesies-spesies lain yang tertangkap jumlahnya kurang dari 10 individu (Tabel 5.).

Hasil tangkapan ikan pada Stasiun 2 sebanyak 17 individu, terdiri dari 9 spesies yang mewakili 8 famili. Spesies-spesies yang mendominasi hasil tangkapan adalah: Priacanthus tayenus dari famili Priacanthidae dengan jumlah tangkapan 5 individu sebagai peringkat pertama; Carangoides $s p$. dari famili Carangidae dengan jumlah tangkapan 3 individu sebagai peringkat kedua; Halieutaea $s p$. dari famili Ogcocephalidae dan Fistularia petimba dari famili Fistularidae dengan jumlah tangkapan 2 individu sebagai peringkat ketiga; Spesies-spesies lain yang tertangkap jumlahnya 1 individu. (Tabel 6.).

Berdasarkan atas jumlah individu dari kedua stasiun, maka spesies-spesies yang mendominasi seluruh tangkapan adalah : Nemipterus tambuloides dari famili Nemipteridae dengan jumlah tangkapan 265 individu ; Priacanthus tayenus dari famili Priacanthidae dengan jumlah tangkapan 99 individu ; Mugil cephalus dari famili Mugilidae dengan jumlah tangkapan 27 individu ; Carangoides talamparoides dari famili Carangidae dengan jumlah tangkapan 25 individu : Leiognathus sp. dari famili Leiognathidae dan Sphyraena sp. dari famili Sphyraenidae dengan jumlah tangkapan 19 individu ; 
Fistularia petimba dari famili Fistularidae dengan jumlah tangkapan 14 individu ; sedangkan spesiesspesies lain yang tertangkap jumlahnya kurang dari 10 individu.

Tabel 4 Ikan-ikan yang tertangkap dengan cantrang di perairan Selat Madura

\begin{tabular}{clrrr}
\hline No & \multicolumn{1}{c}{ Famili } & ST1 (n) & ST2 (n) & $\boldsymbol{\Sigma}$ (n) \\
\hline 1 & Penaeidae & 3 & - & 3 \\
2 & Portunidae & 2 & - & 2 \\
3 & Ogcocephalidae & 4 & 2 & 6 \\
4 & Torpedinidae & 1 & - & 1 \\
5 & Leiognathidae & 19 & - & 19 \\
6 & Carangidae & 42 & 4 & 46 \\
7 & Serranidae & 7 & - & 7 \\
8 & Nemipteridae & 270 & 1 & 271 \\
9 & Priacanthidae & 94 & 5 & 99 \\
10 & Sphyraenidae & 19 & - & 19 \\
11 & Bothidae & 1 & - & 1 \\
12 & Tetraodontidae & 3 & - & 3 \\
13 & Soleidae & 1 & - & 1 \\
14 & Cynoglossidae & 1 & - & 1 \\
15 & Mugilidae & 26 & 1 & 27 \\
16 & Anguillidae & 1 & - & 1 \\
17 & Engraulidae & 6 & - & 6 \\
18 & Fistularidae & 12 & 2 & 14 \\
19 & Platycephalidae & 6 & 1 & 7 \\
20 & Clupeidae & 1 & - & 1 \\
21 & Sepiidae & 5 & - & 5 \\
22 & Monacanthidae & 1 & - & 1 \\
23 & Squillidae & 1 & - & 1 \\
24 & Dasyatidae & 2 & - & 2 \\
25 & Octopusdae & 1 & - & 1 \\
26 & Gerreidae & 1 & - & 1 \\
27 & Loliginidae & 1 & - & 1 \\
28 & Diodontidae & 1 & - & 1 \\
29 & Synodontidae & - & & 1 \\
\hline & & 532 & & 1 \\
\hline & & & - & 1 \\
\hline
\end{tabular}

Tabel 5 Ikan-ikan yang tertangkap pada stasiun 1 dengan cantrang di perairan Selat Madura (S1)

\begin{tabular}{clrr}
\hline No & \multicolumn{1}{c}{ Famili/Spesies } & $\boldsymbol{\Sigma}(\mathrm{n})$ & \multicolumn{1}{c}{$\boldsymbol{\Sigma}(\mathrm{gr})$} \\
\hline 1 & Penaeidae & 3 & \\
& Penaeus semisulcatus & 3 & 900 \\
\hline 2 & Portunidae & 2 & \\
& Portunus pelagicus & 1 & 220 \\
& Portunus haanii & 1 & 80 \\
\hline \multirow{2}{*}{3} & Ogcocephalidae & 4 & \\
& Halieutaea sp. & 4 & 1.600 \\
\hline \multirow{2}{*}{4} & Torpedinidae & 1 & \\
& Torpedo sp. & 1 & 120 \\
\hline \multirow{2}{*}{5} & Leiognathidae & 19 & \\
& Leiognathus sp. & 19 & 760 \\
\hline & & &
\end{tabular}




\begin{tabular}{|c|c|c|c|}
\hline No & Famili/Spesies & $\Sigma(\mathrm{n})$ & $\Sigma(\mathrm{gr})$ \\
\hline \multirow[t]{6}{*}{6} & Carangidae & 42 & \\
\hline & Carangoides talamparoides & 25 & 3.000 \\
\hline & Carangoides sp. & 3 & 1.050 \\
\hline & Decapterus russelli & 6 & 480 \\
\hline & Selar crumenophthalmus & 3 & 210 \\
\hline & Decapterus kurroides & 5 & 550 \\
\hline \multirow[t]{3}{*}{7} & Serranidae & 7 & \\
\hline & Epinephelus sexfasciatus & 5 & 1.500 \\
\hline & Epinephelus sp. & 2 & 620 \\
\hline \multirow[t]{4}{*}{8} & Nemipteridae & 270 & \\
\hline & Nemipterus tambuloides & 264 & 38.450 \\
\hline & Nemipterus nematophorus & 4 & 360 \\
\hline & Nemipterus zysron & 2 & 130 \\
\hline \multirow[t]{2}{*}{9} & Priacanthidae & 94 & \\
\hline & Priacanthus tayenus & 94 & 11.040 \\
\hline \multirow[t]{2}{*}{10} & Sphyraenidae & 19 & \\
\hline & Sphyraena sp. & 19 & 2.090 \\
\hline \multirow[t]{2}{*}{11} & Bothidae & 1 & \\
\hline & Arnoglossus polyspilus & 1 & 230 \\
\hline \multirow[t]{2}{*}{12} & Tetraodontidae & 3 & \\
\hline & Lagocephalus sceleratus & 3 & 210 \\
\hline \multirow[t]{2}{*}{13} & Soleidae & 1 & \\
\hline & Aesopia cornuta & 1 & 100 \\
\hline \multirow[t]{2}{*}{14} & Cynoglossidae & 1 & \\
\hline & Cynoglossus microlepis & 1 & 140 \\
\hline \multirow[t]{2}{*}{15} & Mugilidae & 26 & \\
\hline & Mugil cephalus & 26 & 8.320 \\
\hline \multirow[t]{2}{*}{16} & Anguillidae & 1 & \\
\hline & Anguilla sp. & 1 & 270 \\
\hline \multirow[t]{2}{*}{17} & Engraulidae & 6 & \\
\hline & Encrasicholina sp. & 6 & 960 \\
\hline \multirow[t]{2}{*}{18} & Fistularidae & 12 & \\
\hline & Fistularia petimba & 12 & 360 \\
\hline \multirow[t]{2}{*}{19} & Platycephalidae & 6 & \\
\hline & Sorsogona tuberculata & 6 & 720 \\
\hline \multirow[t]{2}{*}{20} & Clupeidae & 1 & \\
\hline & Dussumieria acuta & 1 & 80 \\
\hline \multirow[t]{2}{*}{21} & Sepiidae & 5 & \\
\hline & Sepia sp. & 5 & 150 \\
\hline \multirow[t]{2}{*}{22} & Monacanthidae & 1 & \\
\hline & Paramonacanthus choirocephalus & 1 & 30 \\
\hline \multirow[t]{2}{*}{23} & Squillidae & 1 & \\
\hline & Harpiosquilla raphidea & 1 & 110 \\
\hline \multirow[t]{2}{*}{24} & Dasyatidae & 2 & \\
\hline & Neotrygon kuhlii & 2 & 740 \\
\hline \multirow[t]{2}{*}{25} & Octopusdae & 1 & \\
\hline & Octopus sp. & 1 & 30 \\
\hline \multirow[t]{2}{*}{26} & Gerreidae & 1 & \\
\hline & Gerres oyena & 1 & 70 \\
\hline
\end{tabular}




\begin{tabular}{|c|c|c|c|}
\hline No & Famili/Spesies & $\Sigma(\mathrm{n})$ & $\Sigma(\mathrm{gr})$ \\
\hline \multirow[t]{2}{*}{27} & Loliginidae & 1 & \\
\hline & Loligo duvauceli & 1 & 40 \\
\hline \multirow[t]{3}{*}{28} & Diodontidae & 1 & \\
\hline & Diodon holocanthus & 1 & 100 \\
\hline & Total & 532 & 75.820 \\
\hline
\end{tabular}

Tabel 6 Ikan-ikan yang tertangkap pada stasiun 2 dengan cantrang di perairan Selat Madura (S2)

\begin{tabular}{|c|c|c|c|}
\hline No & Famili/Spesies & $\Sigma(\mathrm{n})$ & $\Sigma$ (gr) \\
\hline \multirow[t]{2}{*}{1} & Ogcocephalidae & & \\
\hline & Halieutaea sp. & 2 & 720 \\
\hline \multirow[t]{3}{*}{2} & Carangidae & & \\
\hline & Carangoides sp. & 3 & 960 \\
\hline & Seriolina nigrofasciata & 1 & 680 \\
\hline \multirow[t]{2}{*}{3} & Nemipteridae & & \\
\hline & Nemipterus tambuloides & 1 & 260 \\
\hline \multirow[t]{2}{*}{4} & Priacanthidae & & \\
\hline & Priacanthus tayenus & 5 & 750 \\
\hline \multirow[t]{2}{*}{5} & Mugilidae & & \\
\hline & Mugil cephalus & 1 & 300 \\
\hline \multirow[t]{2}{*}{6} & Fistularidae & & \\
\hline & Fistularia petimba & 2 & 60 \\
\hline \multirow[t]{2}{*}{7} & Platycephalidae & & \\
\hline & Sorsogona tuberculata & 1 & 150 \\
\hline \multirow[t]{3}{*}{8} & Synodontidae & & \\
\hline & Saurida tumbil & 1 & 210 \\
\hline & Total & 17 & 4.090 \\
\hline
\end{tabular}

\section{Indeks Kekayaan Spesies}

Hasil perhitungan nilai Indeks Kekayaan Spesies (nilai D) pada dua stasiun pengamatan (Tabel 4.) memperlihatkan, bahwa penyebaran nilai kekayaan spesies berbeda besarnya. Stasiun S1 nilai kekayaan spesies sebesar $(D)=12,83974124$, stasiun S2 nilai $D=6,501692074$. Berdasarkan kriteria indeks kekayaan jenis menurut Jorgensen et al (2005), kondisi kedua stasiun termasuk dalam kategori baik.

\section{KESIMPULAN DAN SARAN}

\section{Kesimpulan}

Hasil penelitian yang telah dilakukan di perairan Selat Madura, dapat disimpulkan bahwa :

1. Spesies-spesies ikan yang mendominasi hasil tangkapan adalah: Nemipterus tambuloides, Priacanthus tayenus, Mugil cephalus, Carangoides talamparoides, Leiognathus sp., Sphyraena sp., Fistularia petimba.

2. Umumnya spesies -spesies yang tertangkap termasuk ikan ekonomis penting.

3. Nilai Indeks Kekayaan Spesies (D) ke dua stasiun termasuk kategori baik.

Saran

Berdasarkan indeks kekayaan jenis ikan, perairan Selat Madura berada dalam kategori baik, agar tidak terjadi over fishing, perlu dilakukan perencanaan pengelolaan kegiatan perikanan tangkap di Selat Madura, sehingga sumberdaya ikan tetap lestari. 


\section{DAFTAR PUSTAKA}

Aji, IN., Wibowo, BA., Asriyanto. 2013. Analisis Faktor Produksi Hasil Tangkapan Alat Tangkap Cantrang di Pangkalan Pendaratan Ikan Bulu Kabupaten Tuban. Journal of Fisheries Resources Utilization Management and Technology. Vol 2 No 4. Hal 50-58.

Allen, G. R. 2000. Marine fishes of South -East Asia. Periplus, Singapore: 292 pp.

Allen, G. R., Steene, R., Humann, P. \& Deloach, N. 2003. Reef fish identification: Tropical Pacific. New World Publication, Inc., USA: 457 pp.

Bambang N (editor). 2006. Petunjuk Pembuatan dan Pengoperasian Cantrang dan Rawai Dasar Pantai Utara Jawa Tengah. Balai Besar Pengembangan Penangkapan Ikan. Direktorat Jenderal Perikanan Tangkap. Departemen Kelautan dan Perikanan. Semarang.

Carpenter, K. E. \& Niem, V. H. 1999a. FAO species identification guide for fishery purposes: The living marine resources of the Western Central Pacific. Batoid fishes, chimaeras and bony fishes part 1 (Elopidae to Linophrynidae) (Vol. 3). FAO, Rome: 1540-2068.

Carpenter, K. E. \& Niem, V. H. 1999b. FAO species identification guide for fishery purposes: The Living Marine Resources Of The Western Central Pacific. Bony Fishes Part 2 (Mugilidae To Carangidae) (Vol. 4). FAO, Rome: 2069-2789 pp.

Carpenter, K. E. \& Niem, V. H. 2001a. The Living Marine Resources Of The Western Central Pacific. Bony fishes part 4 (Labridae to Latimeriidae), estuarine crocodiles, sea turtles, sea snakes and marine mammals (Vol. 6). FAO, Rome: 3381-3970 pp.

Carpenter, K. E. \& Niem, V. H. 2001b. FAO species identification guide for fishery purposes: The Living Marine Resources Of The Western Central Pacific. Bony fishes part 3 (Menidae to Pomacentridae) (Vol. 5). FAO, Rome: 2791-3380 pp.

Dinas Perikanan dan Kelautan Provinsi Jawa Timur. 2014. Laporan Tahunan Statistik Perikanan Tangkap di Jawa Timur Tahun 2014. Surabaya. 80hal.

https://jatim.bps.go.id/statictable/2018/02/08/894/produksi-perikanan-tangkap-perikanan-lautmenurut-kabupaten-kota-di-jawa-timur-tahun-2010-2016-ton-.html (diakses tanggal 31 Agustus 2018, 14:49 WIB)

Jorgensen, S.E., R. Constanza \& F.L. Xu. 2005. Handbook of Ecological Indicators for Assesment of Ecosystem Health. CRC Press. www.crepress.com.

Margalef, D.R. 1958. Information Theory in Ecology. General System 3. 36-71.

Odum, E. P. 1971. Fundamental of Ecology. W. B. Sounders Company. Philadelphia, London. 
Lampiran 1. Gambar jenis ikan hasil tangkapan
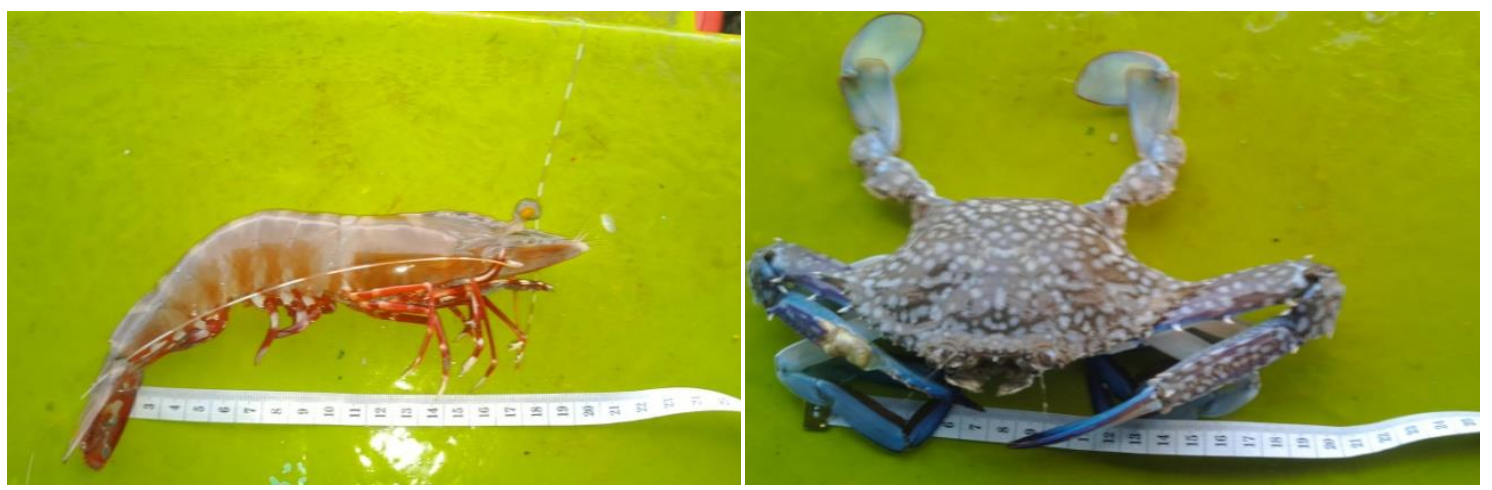

\section{Penaeus semisulcatus}

\section{Portunus pelagicus}

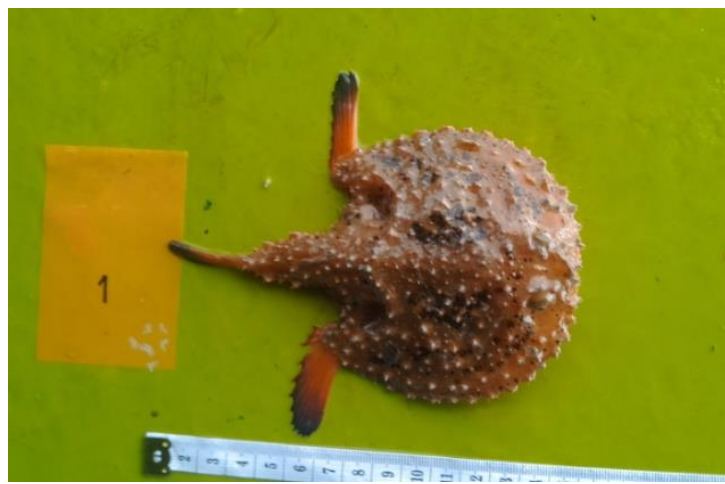

Halieutaea sp.
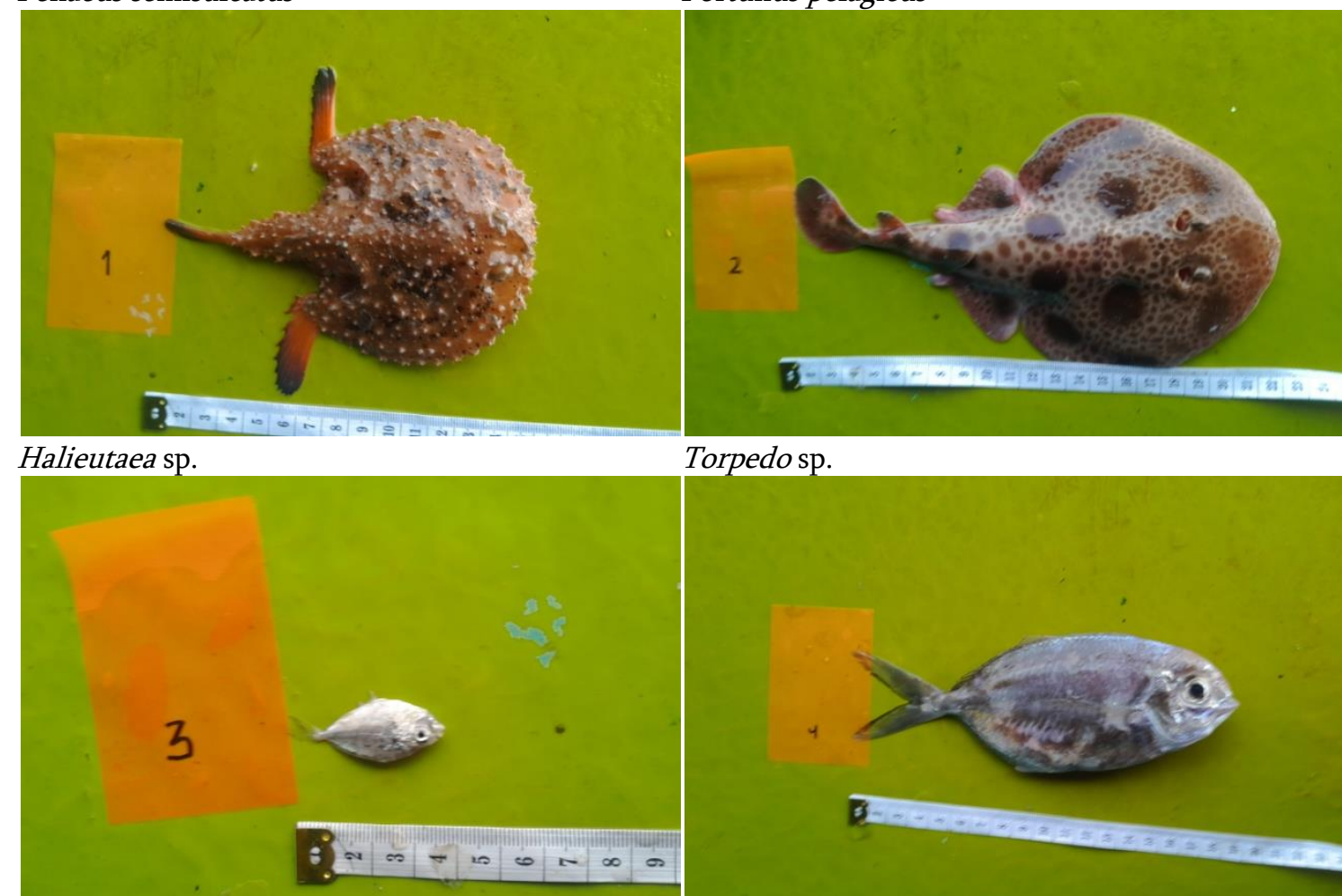

Torpedo sp.

Leiognathus sp.

\section{Carangoides talamparoides}
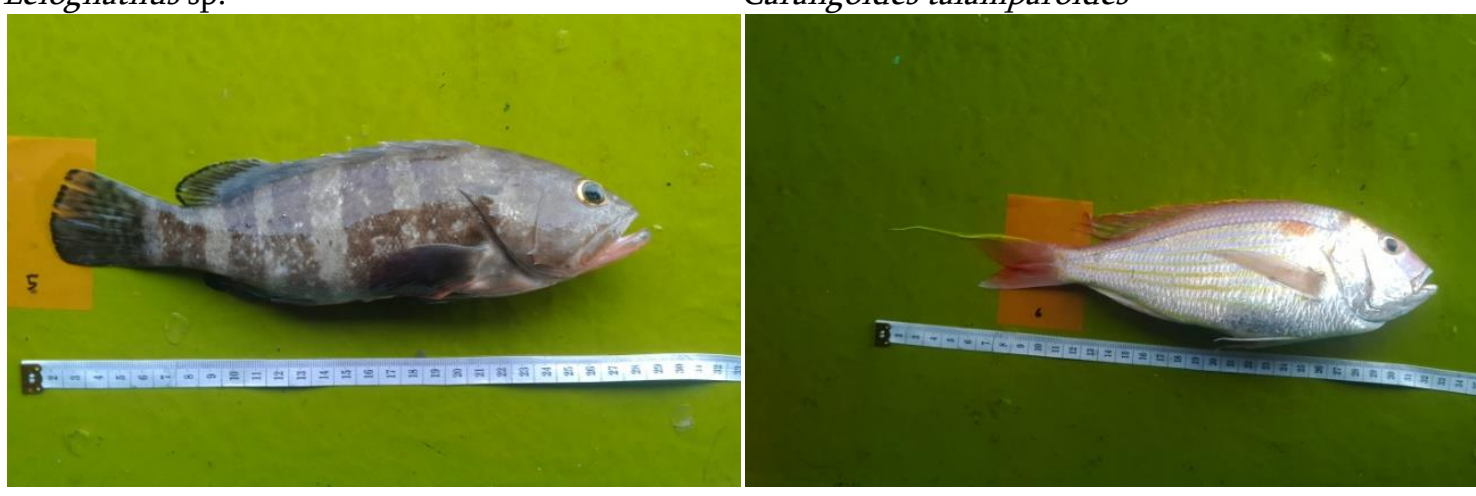

Nemipterus tambuloides 

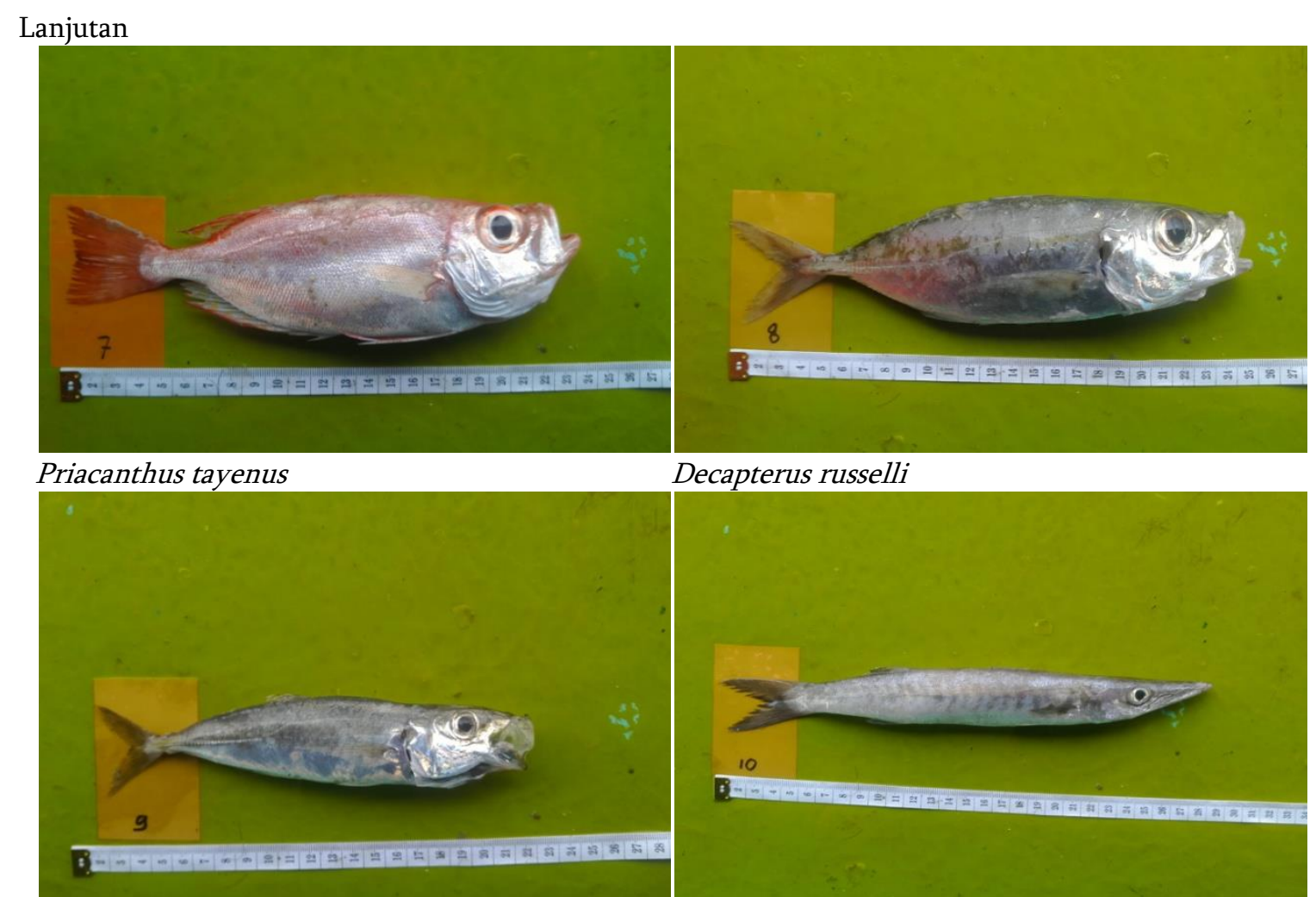

\section{Decapterus russelli}

\section{Selar crumenophthalmus}

\section{Sphyraena sp.}
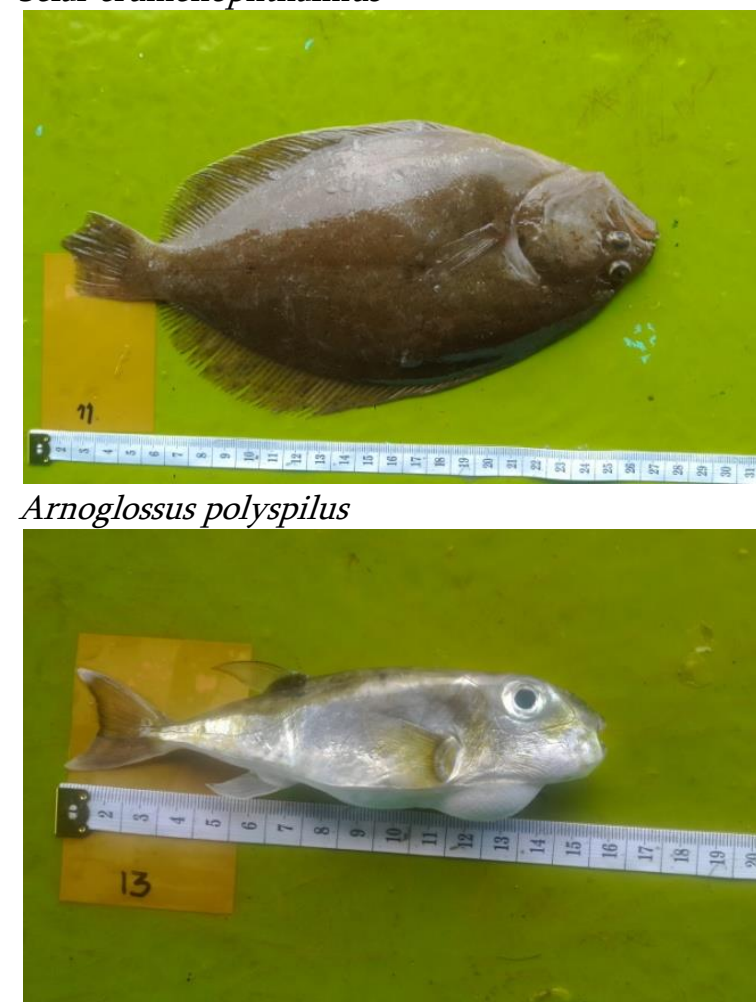

\section{Decapterus kurroides}

Lagocephalus sceleratus

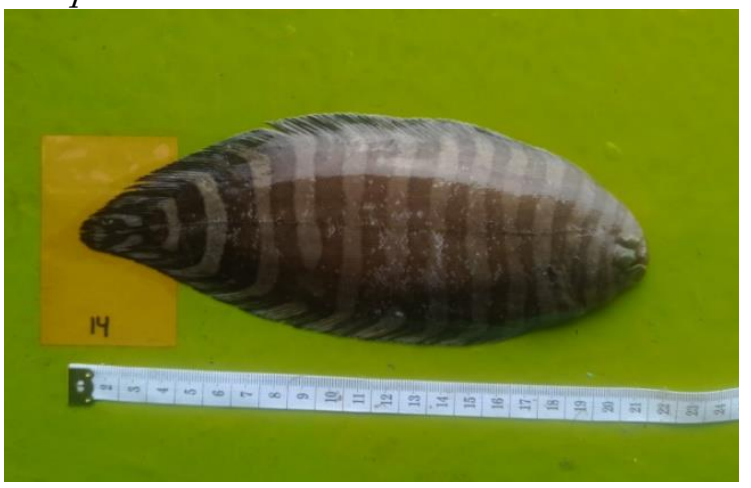

Aesopia cornuta 

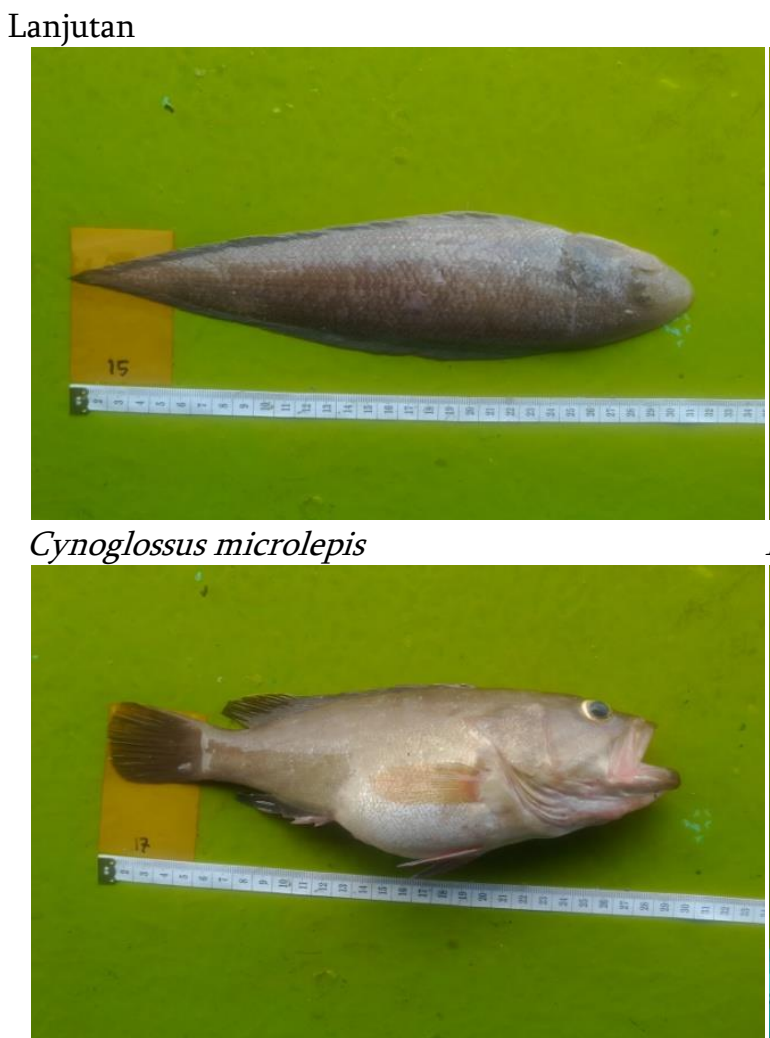

\section{Mugil cephalus}

Epinephelus sp. Anguilla sp.
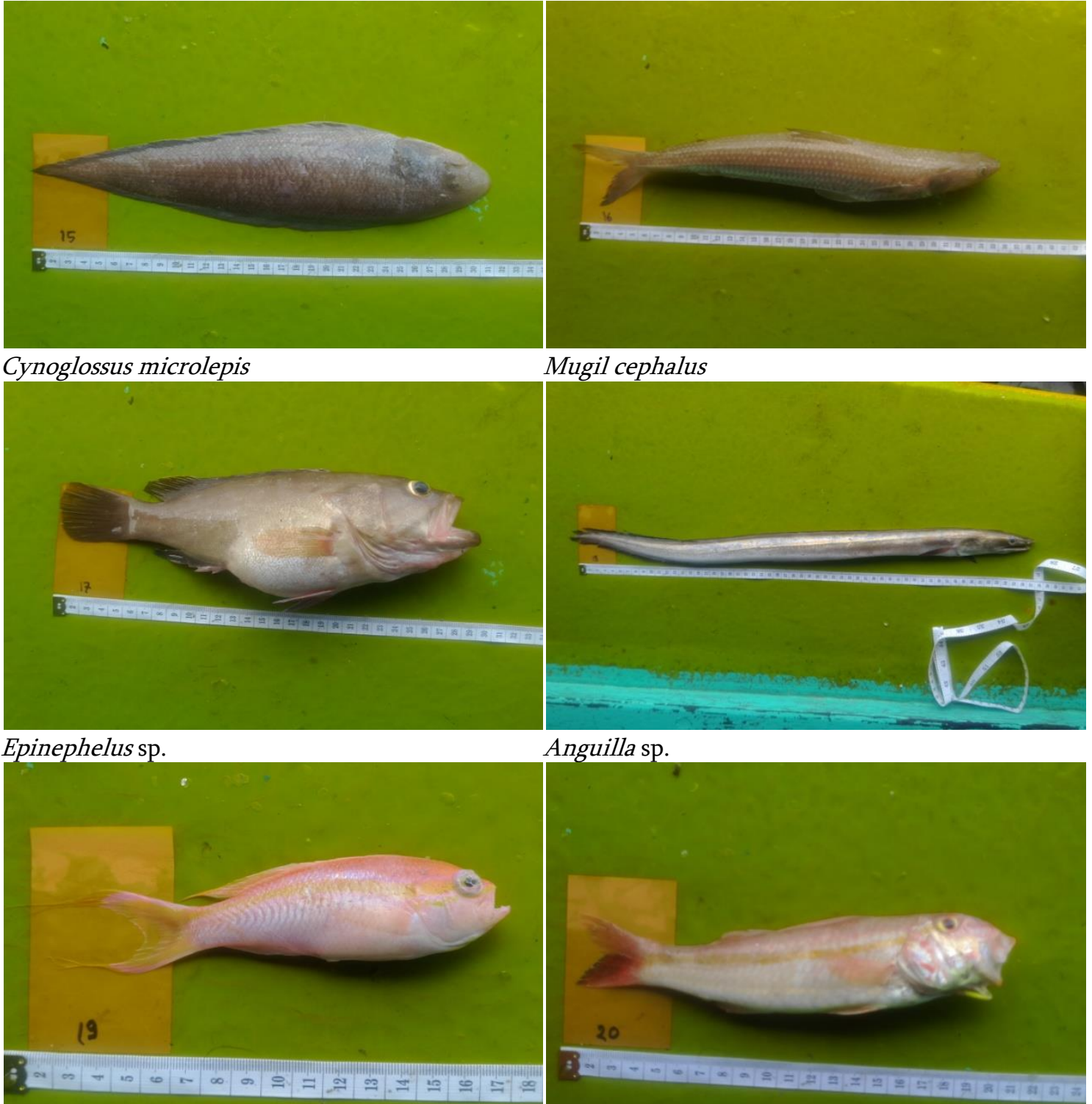

\section{Nemipterus nematophorus}
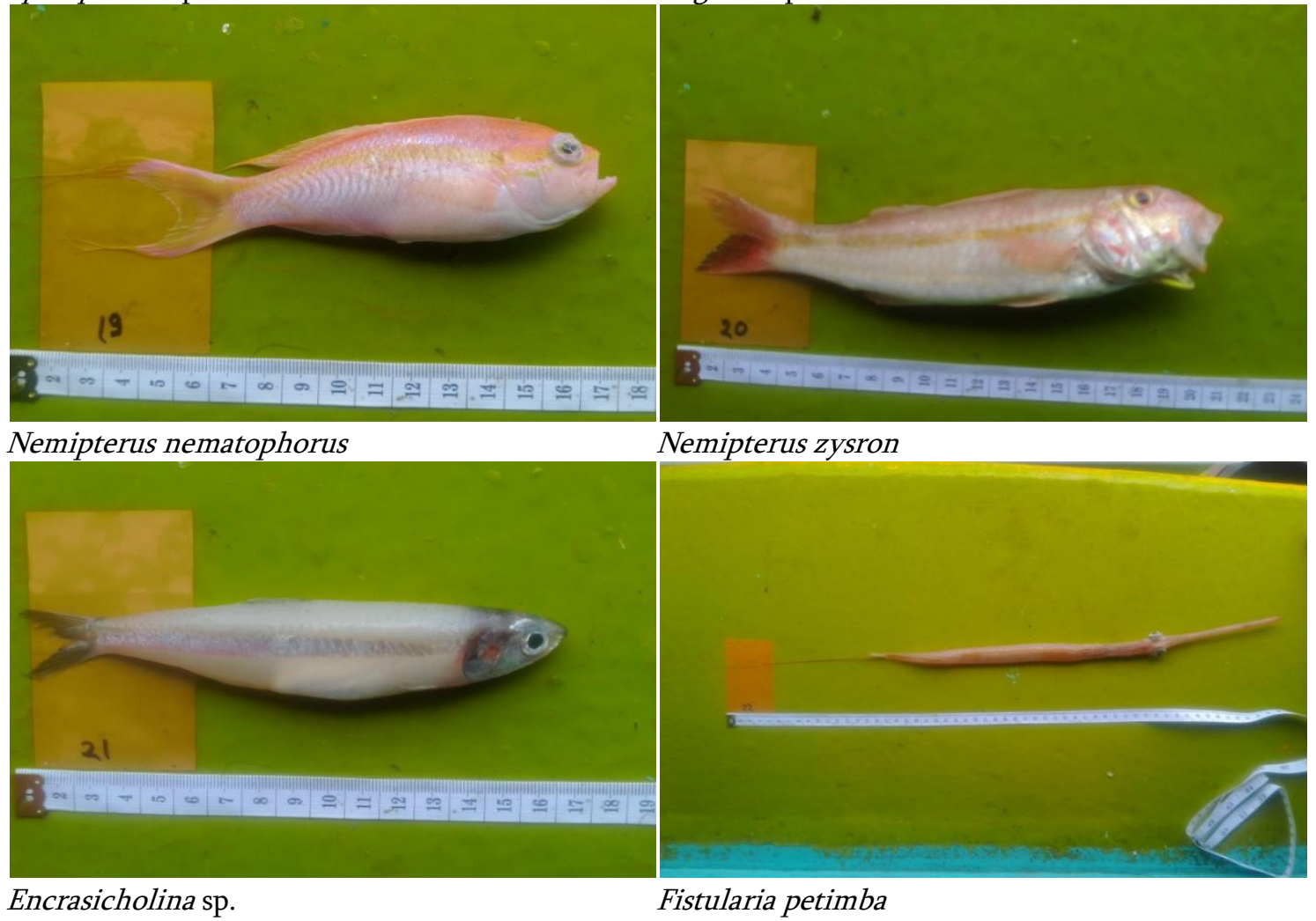

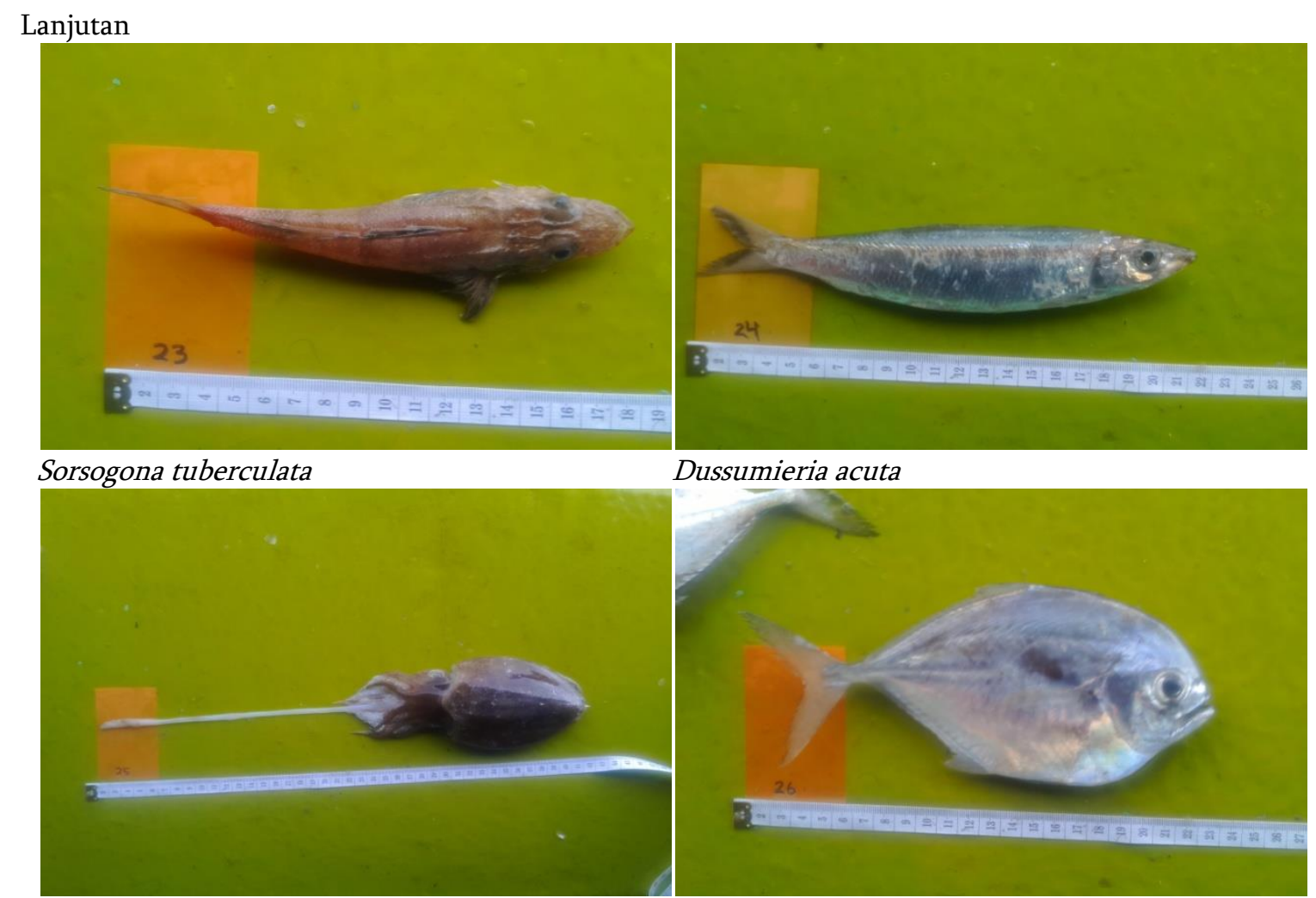

Dussumieria acuta

Sepia sp.

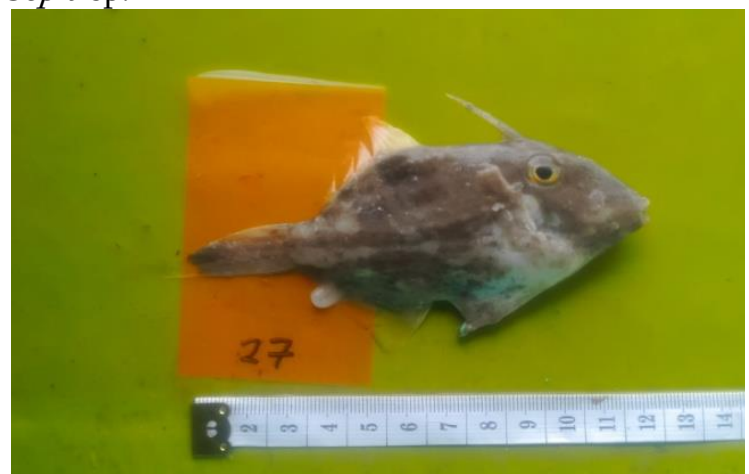

Paramonacanthus choirocephalus

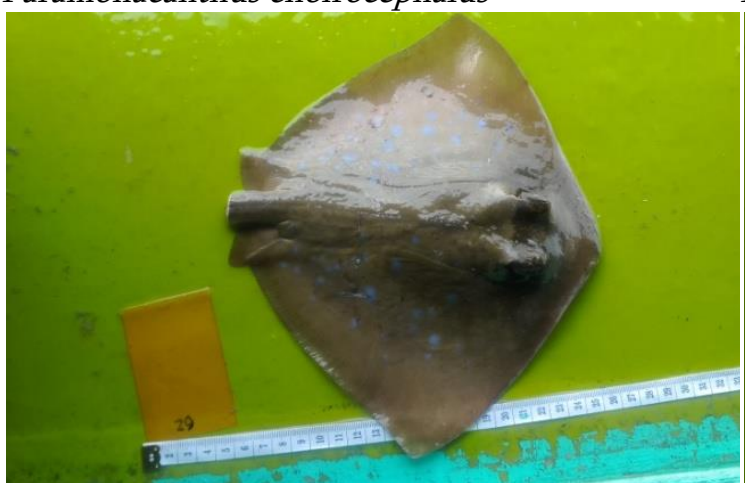

Neotrygon kuhlii

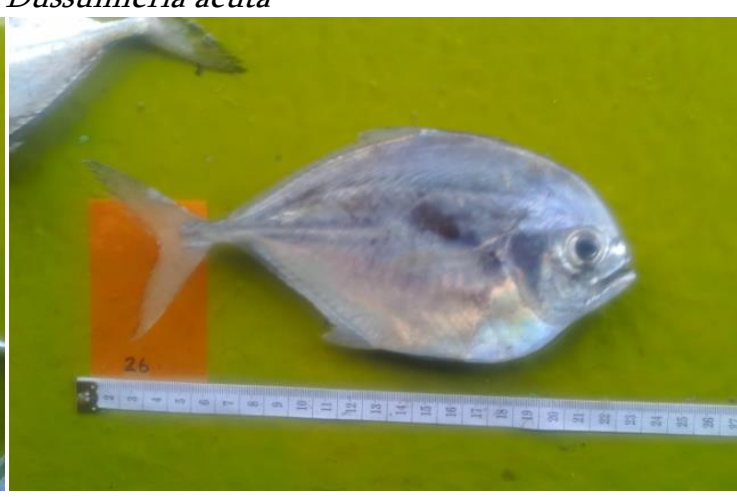

Carangoides sp.

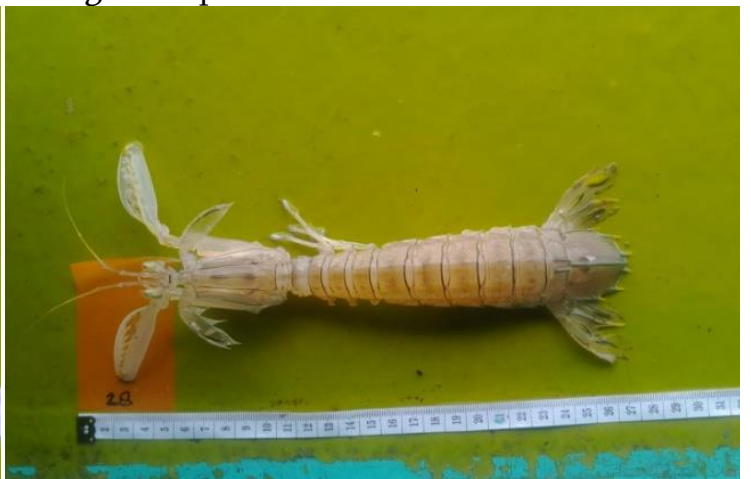

\section{Harpiosquilla raphidea}

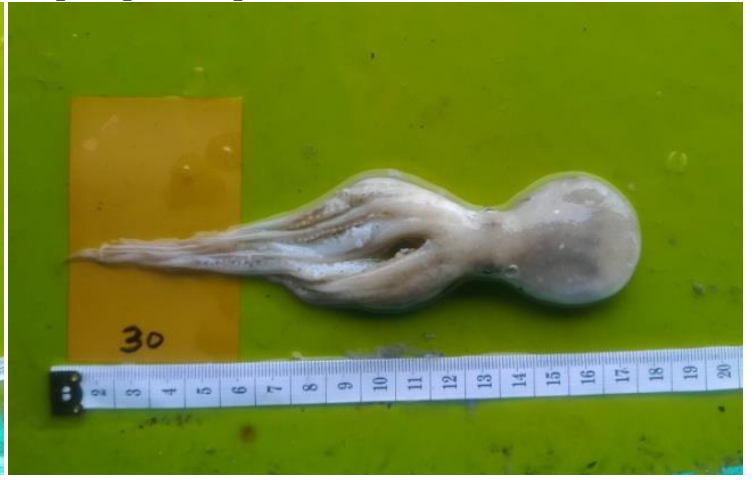

Octopus sp. 


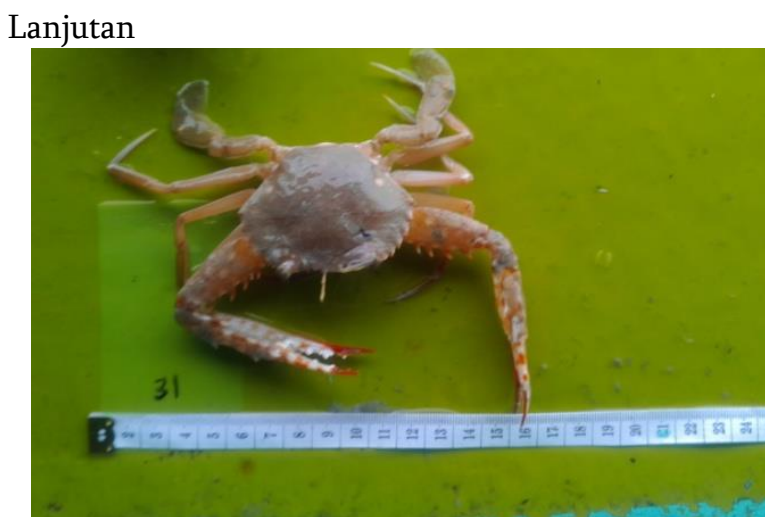

Portunus haanii
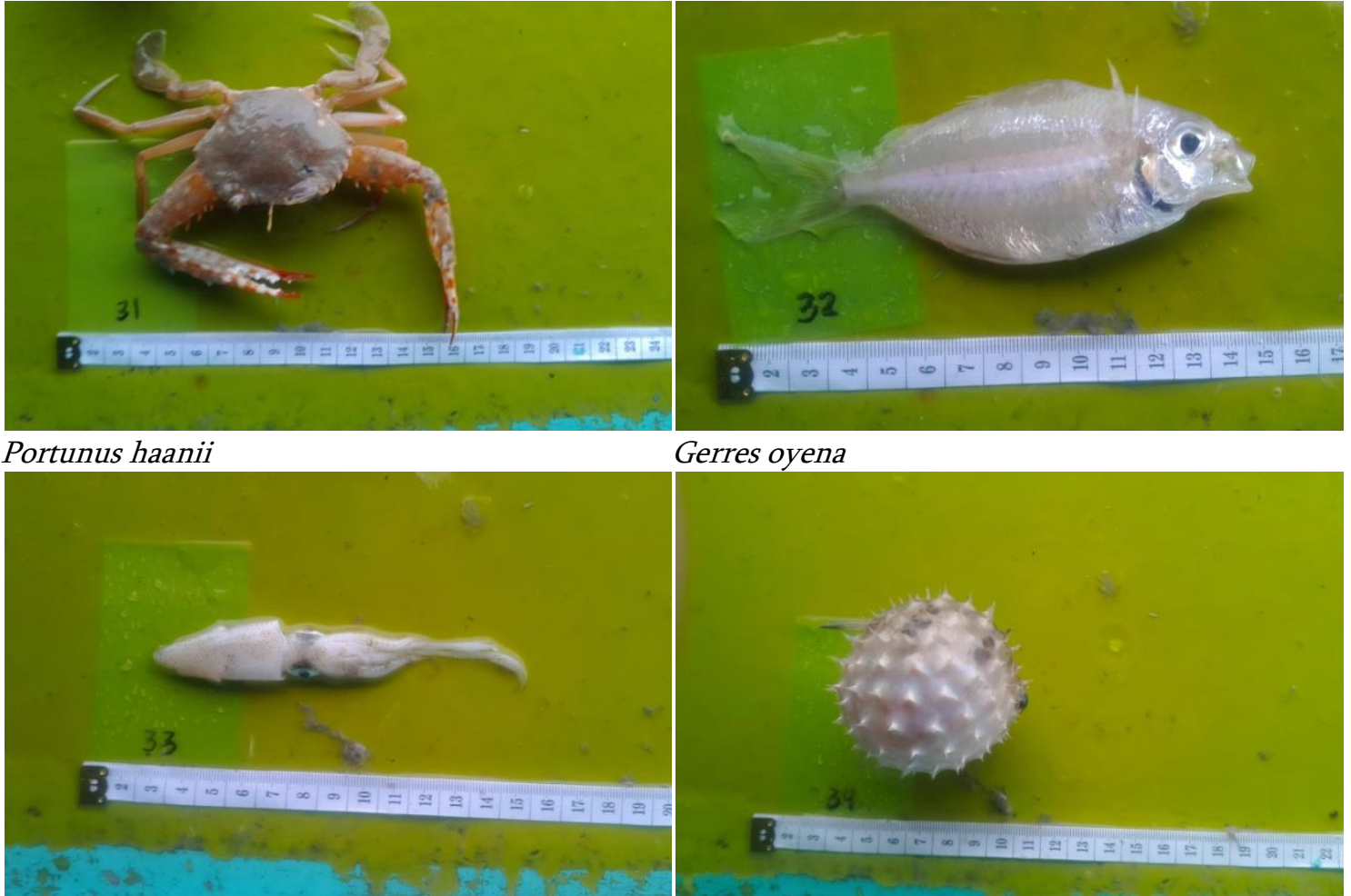

Gerres oyena

Loligo duvauceli

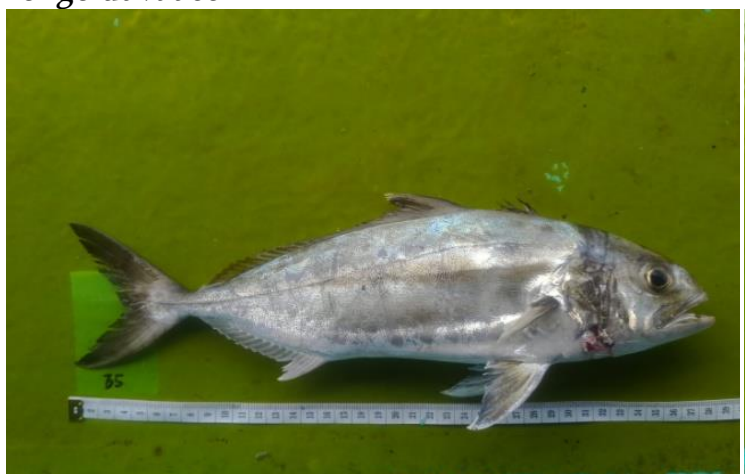

Seriolina nigrofasciata

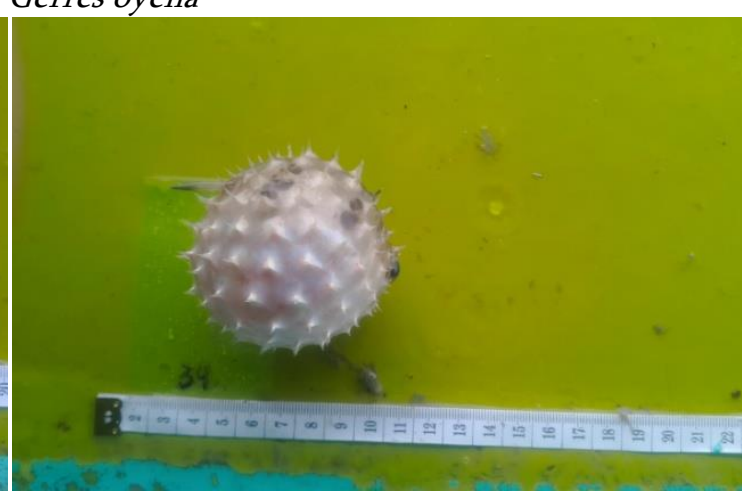

Diodon holocanthus

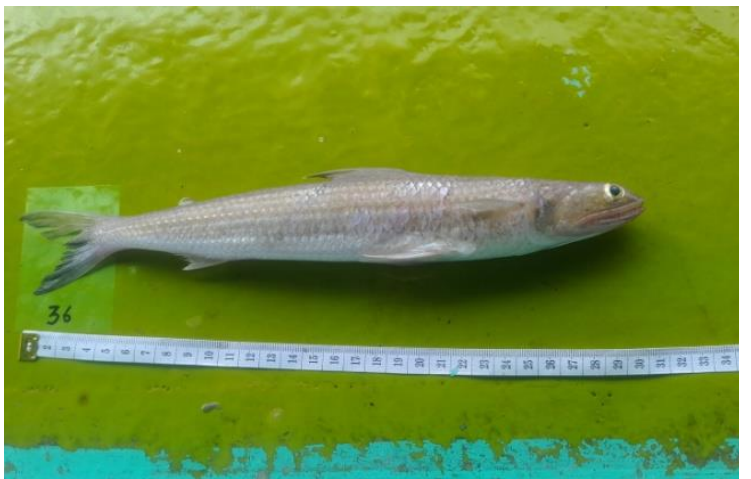

Saurida tumbil 